\title{
Seyahat Notları ve Oryantalist Bilgi Üretimi: Eduard Sachau (1845-1930) Örneği
}

\author{
Remzi Aveı (i), Mardin \\ https://dx.doi.org/10.37583/diyalog.759411
}

$\ddot{O} z$

19. yüzyılda misyoner, oryantalist, asker, yönetici ve araştırmacılar olmak üzere farklı meslek gruplarından birçok Avrupalı, Osmanlı topraklarını dolaşarak arkalarında seyahat kitapları bırakmışlardır. Klasik bilimsel çalışmaların aksine alternatif bir araştırma modeli olarak kabul edilebilecek olan seyahat yazını bir anlatı türü olarak sosyal bilimlerin farklı disiplinleri için oldukça sübjektif verilere dayansa da yoğun ve zengin bir bilimsel materyal sunmaktadır. Bu bağlamda bir Alman oryantalist ve seyyah olan Eduard Sachau (1845-1930) Osmanlı toprakları içerisinde 1879'da başlayarak yaklaşık altı ay süren bir seyahat gerçekleştirmiş ve seyahat notlarını Reise in Syrien und Mesopotamien (Suriye ve Mezopotamya Seyahati) adıyla 1883 yılında Almanya'da kitap olarak yayımlamıştır. Aslında bir filolog olan Sachau, tıpkı bir sosyolog, antropolog ve arkeolog gibi dolaşarak Osmanlı taşrasında yaşayan Arap, Kürt, Türk, Nasturi, Yakubi ve Yezidiler hakkında önemli bilgiler sunmuştur. Bu çalışma, bir bilim insanı olarak Sachau'nun seyahatinin oryantalist bilgi üretim süreci olduğunu iddia etmekte ve onun süreçte bu topladığı bilgiyi farklı yollarla akademik metinlere transfer ettiğini öne sürmektedir.

Anahtar Sözcükler: Sachau, Seyahat, oryantalizm, bilgi, Osmanlı, Doğu, Almanya

\section{Abstract}

Travel Notes and the Production of Orientalist Knowledge: The Case of Eduard Sachau (1845-1930)

In the $19^{\text {th }}$ century, many Europeans from different professions, including missionaries, orientalists, soldiers, administrators and researchers, travelled around Ottoman territories and left books behind. Contrary to classical scientific studies, travel writing can be considered as an alternative research model. Although travelogues are based on highly subjective data for the social science as a narrative genre, it provides intense and rich scientific materials. In this context, Eduard Sachau (1845-1930), a German orientalist and traveller, made a journey within the Ottoman territory in 1879, which lasted about six months. He then published his notes as a book in 1883 in Germany under the title Reise in Syrien und Mesopotamien (Journey to Syria and Mesopotamia). Although Sachau was originally a philologist, he travelled as a sociologist, anthropologist and archaeologist, and provided important information about the Arabs, Kurds, Turks, Nesturian, Yakubi and Yezidis who lived on Ottoman territory. This article firstly claims that Sachau's travel is a process of orientalist-knowledge production. Secondly, it demonstrates how he converted these collected information into academic texts in different ways.

Keywords: Sachau, travel, orientalism, knowledge, Ottoman, Orient, Germany 


\section{EXTENDED ABSTRACT}

In the $19^{\text {th }}$ century, many Europeans from different professions, including missionaries, orientalists, soldiers, administrators and researchers, travelled around the Ottoman territories and left travel books behind. In comparison with classical scientific studies, travelogue can be regarded as an alternative research model. Although this kind of writing is based on highly subjective data as a narrative genre, it provides intense and rich scientific materials. The widespread use of modern transportation vehicles such as trains, steam ships, and scientific developments in the fields of geography and cartography played a triggering role in the increase of travel in this period. In this context, Eduard Sachau (1845-1930), a German orientalist and traveler, made a journey on the Ottoman territory in 1879 , which lasted about six months. He then published his travel notes as a book in 1883 in Germany under the title Reise in Syrien und Mesopotamien (Journey to Syria and Mesopotamia), which gives detailed information about Beirut, Damascus, Urfa, Raqqa, Deir ez-Zor, Mosul, Cizre, Midyat, Mardin, Diyarbakir, Aleppo and Hatay. After his travels in the Orient between 1897 and 1898, in 1900, he published his other book under the title Am Euphrat und Tigris (In Euphrates and Tigris). Both travels were financed by the Königlich-Preußische Akademie der Wissenschaften (The Royal Prussian Academy of Sciences) in Berlin. Since the second half of the 19th century, Prussian Academy financially supported many scientific travels and expeditions, ranging from archaeology to geography, zoology and botany. However, in the Ottoman Empire it was archaeological travels and excavations that received special sponsorship, especially at the time when a relationship began to develop between the Ottoman and German Empire. In the broad region of the Ottoman Empire, where Sachau wandered from rural to urban centres without being constrained by borders. Sachau's travel constitutes a good example of cultural transfer between Orient and Occident.

Although Sachau was originally a philologist, he collected multifaceted data about the Arabs, Kurds, Turks, Nestorians, Jakobites and Yezidis who lived in Ottoman lands. During his travel, Sachau gave detailed information on topics regarding geography, history, politics, anthropology, sociology, philology, religion, sect, geology, archaeology, art and urban history. He followed a certain roadmap and had a particular agenda. His journey was quite different from other travelers who were in pursuit of adventure, pleasure and exoticism. In addition to publishing his impressions as a book, Sachau also produced philological and archaeological works that were based on them. In this context, travel is the process of science production, namely the production of orientalist knowledge from impressions and narratives. His memory, notebook, speeches, relationships and people in the Orient can be considered as the storage and source of knowledge. A strong network, mobilization, close proximity to local authorities and notables of the region made an important contribution to this process. Placing his sociological-anthropological and political observations at the centre of the text, Sachau succeeded in turning this data into a unique methodology. In other words, Sachau's work made it possible to conduct scientific studies by producing information from his impressions and transfering them to the West as material of orientalism. On his journey, Sachau came into contact with local people. He managed to make these people 
material of anthropology, from their everyday lives, to their costume, from their cuisine to their religious rituals and to their warming traditions in a world that was completely alien to his culture. Sachau saw with his own eyes the Ottoman famine of 1879-1881, which affected the eastern provinces of the empire, and he analyzed its inevitable sociological and economic consequences in different regions and societies. Besides, he made also political observations on the Ottoman Empire. In his narratives, one can find quite a lot of information about the Ottoman provincial administration from the description of an ordinary event. Sachau undertook his travels for research purposes and did not pursue an imperial objective. Yet these travels can be also described as an attempt to find possibilities for German imperialism in the Ottoman territory. This is evident from the rivalry with the activities of the dominant French and British travelers and orientalists in the Ottoman territory. This study claims that Sachau's travel is a process of orientalist-knowledge production and that he converted the information he had collected during his journey into academic texts of different nature. 


\section{Giriş}

Gerçek bir yolculuğun ardından bir metne dönüşmüş olan seyahat izlenim ve anlatıları, Batı edebiyatının en eski türlerinden biri olarak kabul edilir ve Antik Yunan dönemlerine kadar uzanır (Brenner 1990: 1). İslam dünyasının Batılı seyyahlar aracılığı ile tasvir edilmesi oldukça eski bir gelenektir. Ortaçağ' da İslam'ın siyasal bir güç olarak ortaya çıktığ1 dönemde İslam'1 yakından tanıma düşüncesi Doğu'ya seyahati tetikleyen önemli nedenlerden biri olmuştur. Hristiyan hacıların ve Haçlı Seferleri'ne katılanların seyahat anlatıları İslam dünyasını yakından tanınmasında ilk örnekler olarak ele almak da mümkündür.

Doğu'nun zenginliklerine ulaşmak için İslam dünyasına seyahat eden "tacir ve diplomatları" daha sonraki süreçte Doğu'nun daha özelde İslam dünyasının medeniyet ve dinlerine ilgi duyan ve yakından tanımak isteyen "araştırmacı ve maceraperestler" takip etmişlerdir (Bulut 2014: 63). Bu husus, 18. yüzyılda seyahatin "edebi” yapısından ziyade hangi oranda bilgi ürettiği ve aktardığı ile daha dikkat çekici bir duruma dönüşmüştür, yani estetik yapısından ziyade güvenirliği, gerçekliği ve sahada ne kadar bilgi inşa ettiği meselesi artarak daha fazla önem kazanmıştır (Brenner 1990: 1). "Metinsel orijinalliği” ise anlatının gerçeğe ne kadar yakın olduğu ile ilişkilidir. Estetik ve anlatının zenginliği bir seyahatin epistemik açıdan değerli olması için kendi başına yeterli bir kriter olarak değerlendirilemez (Soukah 2016: 36). Literatürde "seyahat yüzyılı" olarak adlandırılan 18. yüzyılda (Unverhaun 2012: 104) temel olarak bilimsel araştırma amaçlı yeni formda bir seyahat modelinin artık gelişmeye başladığı söylenebilir (Soukah 2016: 40). Edebi seyahat yazınının yanı sıra profesyonel olan ve farklı alanları içerisine alan seyahat literatürünün 19 . yüzyılda ortaya çıktığı söylenebilir. Bu dönemde seyahat literatürü bir yazın türü olarak Batı'da oldukça geniş bir okur kitlesine ulaşmıştır. Seyahat edemeyenler, edenlerin yazdıkları sonucunda ortaya çıkan külliyat ile yetinmek zorunda kalmışlardır. 19. yüzyılın ikinci yarısında İslam dünyası birçok Batılı seyyahın önemli bir menzili haline gelmiştir. Zengin Doğu seyahatleri külliyatı bunun en somut kanıtı olarak görülebilir (Soukah 2010: 2-5). Tarih boyunca misyoner, oryantalist, asker, yönetici ve araştırmacılar olmak üzere farklı meslek gruplarından insanlar arkalarında seyahat kitapları bırakmışlardır. 19. Yüzyılda ortaya çıkan seyahat yazını emperyalizmin kültürel bir ürünü olarak da ele alınabilir. $\mathrm{Bu}$ dönemde sömürgeciliğin kurumsallaşmasına katkı sunan ya da sömürgeciliğin altyapısını inşa için gerekli bilgileri üreten türde seyahat eserleri de kaleme alınmıştır. Buna verilecek en somut veri başlangıçta bireysel yapılan seyahatlerin bir kısmının 19. yüzyılda resmî ya da yarı resmî devlet kurumları tarafından desteklenmesidir (EdwardsGraulund 2011: 1; Prass 2019: 1). Bunun yanı sira tren, buharlı gemiler gibi modern ulaşım araçlarının yaygınlaşması, coğrafya ve haritacılık alanlarındaki bilimsel gelişmeler de bu dönemde seyahatlerin artmasında tetikleyici bir rol oynamıştır.

Sömürgeciliğin yaygınlaşması Batılı devletlerin vatandaşlarının daha özgür ve daha rahat hareket edebilmelerine imkân sağlamıştır. Farklı milletlerden seyyahların 19. yüzyılda Doğu'ya akınları ile "mantar gibi çoğalan büyük projeler, dünyaya çeki düzen verme planları, seyahat öyküleri” Avrupa dışındaki ülkeler ile ilgili bilgiler birbirini izlemiştir (Hentsch 2008: 128). Seyahat yazını klasik bilimsel çalışmaların aksine 
“alternatif” bir araştırma modeli olarak kabul edilebilir. Zira seyahatler bir anlatı türü olarak sosyal bilim disiplinleri için oldukça kişisel ve sübjektif verilere dayanmaktadırlar (Sharp 2002: 155). Seyyahların bazen oldukça abartılı ve fantastik hikâyelerinin yanı sıra bazen de hiç görmedikleri yerleri kendi hayal güçleri ile zenginleştirerek yazmaları, ilk ortaya çıktıkları dönemden günümüze kadar seyahat notlarına kuşku ile bakılmasına neden olmuştur. Bu durum seyahat esnasında kaleme alınan mektup ve günlük gibi edebi metinler ile seyahat raporlarının birbirlerine karışması sonucunu doğurmuştur (Brenner 1990: 1). Buna rağmen Doğu'nun romantize edilmesinde seyahatlerin çok ciddi bir rolü olduğu söylenebilir. Zira seyyahların izlenimlerini aktarmaları Batı'da daha fazla insanın Doğu'ya ilgi duyarak yola çıkmasına bir neden olmuştur. Başlangıçta beraberlerinde ilginç hikâyeler ve bilimsel materyaller getiren seyyahların "sonraki yüzyıllarda gemiler dolusu heykeller, kabartmalar, dikili taşlar, değerli eşyalar ile" dönmeleri daha sonra onlara kuşku ile bakılmasına kapı açmıştır (Bulut 2014: 63; Hentsch 2008: 128). Seyyahların yazmaları Batı'ya taşıyarak Avrupa bilim dünyasına kazandırmaları oryantalizm ile seyyahların yollarının kesişmesine neden olmuş ve Doğu çalışmalarının gelişip zenginleşmesine imkân sağlamıştır.

$\mathrm{Bu}$ bağlamda ele alınabilecek seyahatlerden biri de bu çalışmanın konusu olan oryantalist Eduard Sachau'nun 1879'da Osmanlı topraklarına yaptığı ve 1883'de kitaplaştırdığı Reise in Syrien und Mesopotamien (Mezopotamya ve Suriye Seyahati) adlı seyahatidir (1883). Doğu bilgisinin zenginleşmesinde önemli bir katkısı olan Sachau'nun söz konusu seyahati Berlin'de bulunan Königlich-Preußischen Akademie der Wissenschaften (Prusya-Krallığı Bilimler Akademisi) tarafından finanse edilmiştir (BArch R 901/ 37739, 8). ${ }^{1} 11$ Temmuz 1700'de elektör III. Friedrich kurulan bu dernek 1809 yılına kadar finansal olarak bağımsız hareket etmiş daha sonra Berlin'de bulunan Friedrich-Wilhelms Üniversitesi'ne entegre edilmiştir. 19. yüzyılın ikinci yarısından itibaren söz konusu kuruluş arkeolojiden, coğrafya ve botaniğe kadar çok farklı alanlardan birçok bilimsel seyahati finansal olarak desteklemiştir. Osmanlı topraklarında ise daha çok arkeolojik seyahat ve kazıları desteklediği söylenebilir. Carl Friedrich Lehmann-Haupt (1861-1938), Waldemar Belck (1862-1932), Walter Judaic, Carl Human gibi araştırmacılar Osmanlı Devleti'nde yaptıkları çalışmalar için bu kuruluşça desteklenmiştir (Gülçur 2013: 45). Bunun en ciddi gerekçesi söz konusu derneğin özellikle 'Ortadoğu'daki' arkeolojik kazıları Alman İmparatorluğu'nun kültür politikasının bir parçası olarak algılamasından kaynaklanmaktadır (Hanisch 2003: 33). 19. yüzyılın sonlarında ve 20. yüzyılın başlarında Friedrich Paul Theodor Sarre (18651945), (1895) Ernst Herzfeld (1879-1948), (1911 ve 1920)² Belck (1893) ${ }^{3}$ Lehmann-

\footnotetext{
${ }^{1}$ Sachau'nun Alman Dışişleri Bakanlı̆̆ı’'na 25 Haziran 1879 tarihli mektubu, Das Bundesarchiv (BArch) Berlin-Lichterfelde R 901/ 37739 klasör içerisinde, 8.

${ }^{2}$ Herzfeld'in Sarre ile beraber yaptıkları bu seyahatin sonucunda Mezopotamya İslam arkeolojisi ve İran sanatı üzerine ortaya dört ciltlik bir çalışma çıkmıştır.

${ }^{3}$ Aslında kimyacı olan ve alaylı bir arkeolog olan değerlendirilen Belck, Doğu Anadolu'da yaptı̆̆ seyahatlerde Van Gölü çevresi Kafkasya'da Ermeni coğrafyasında araştırmalar yapmış Kaldea kalıntı ve kitabelerine ulaşmıştır.
} 
Haupt (1899) ${ }^{4}$ Martin Hartmann (1851-1918) (1913) $)^{5}$, Oskar Mann (1867-1917) (2014) ${ }^{6}$ ve Max von Oppenheim (1860-1946) (1899) ${ }^{7}$ gibi birçok mektepli ve alaylı oryantalist Osmanlı topraklarında seyahat etmiş ve akabinde seyahat notlarını kitaplaştırmışlardır.

Dünya literatüründe seyahatleri farklı devlet tecrübelerinde inceleyen oldukça zengin bir literatür mevcuttur. Alman oryantalizmine filolojik eserleri başta olmak üzere farklı alanlarda eserler bırakan Sachau hakkında müstakil çalışmalar yapılmamıştır. Sachau ismine ve geride bıraktıklarına Alman oryantalizmini konu alan çalışmalarda sıklıkla rastlanılabilir. Batılı seyyahların daha özelde Alman seyyahların Doğu ile yoğun ilişkileri ve bu ilişkilerin bir sonucu olarak ortaya bazı metinlerin çıkması aynı zamanda Batı'da okurların "kolektif hafızalarında" Doğu ile ilgili belirli kalıplaşmış yargıların stereotiplerin oluşmasına yol açmıştır (Soukah 2010: 2- 5). Seyyahlar üzerine yapılan çalışmalar genelde Edward Said'in oryantalizm tezleri üzerinden şekillenmiştir. Söz konusu çalışmalar seyyahların nasıl bir Doğu tasavvuruna sahip olduklarını ve Doğu'yu hangi kültürel kalıplar ile tasvir ettiklerine odaklanmışlardır. Oryantalizmi akademik bir disiplin olarak ele alan bu çalışma, Sachau'nun Doğu'yu hangi kalıplaşmış yargılar üzerinden tanımladığından ziyade onun oryantalist bilgiyi metne dönüştürme sürecini merkeze almıştır. İlk olarak Sachau'nun seyahatinin bir oryantalist bilgi üretim süreci olduğunu iddia eden bu makale, sahadan örneklerle bunu desteklemektedir. İkinci olarak ise, üretilen bu bilginin seyahatin ardından akademik bir metne nasıl dönüştüğünü ortaya koymayı denemektedir. Bunların yanı sıra bu çalışmada Sachau anlatısında Osmanlı toplumunda kültürler-arası geçişkenlik, dilin, mezhebin ve siyasetin işlevselliği ve bunların fonksiyonlarını nerede ve nasıl yitirdiği tartışılarak bu seyahatin dil kültür ve antropolojisinin anlaşılmasında nasıl bir katk1 sunduğunu ortaya koyacaktır.

Bu makale üç bölümden meydana gelmektedir. Birinci bölüm, Sachau'nun çok kısa akademik biyografisini ve onun seyahatini ele almaktadır. İkinci bölüm Sachau'nun sahadaki belirli pratiklerden hareketle bilgi üretim sürecine ve bilgiyi elde etme metodolojisine odaklanmaktadır. Üçüncü bölüm ise onun topladığı bilgileri akademik metne nasıl transfer ettiğini incelemektedir.

\section{Eduard Sachau (1845-1930) ve Seyahati}

Sachau, 1867'de Kiel ve özellikle Leipzig'de birçok oryantalisti yetiştiren “Alman oryantalizminin babası kabul edilen Filolog- Arabist Heinrich Leberecht Fleischer'in (1801-1888) (Becker 1932: 458) öğrencisidir. Metodolojik olarak Fleischer'in filolojik

\footnotetext{
${ }^{4}$ Lehman-Haupt, özellikle Doğu Anadolu’da Urartu ve Kaldealılar üzerine keşifler yapmıştır.

5 Arabiyatçı filolog ve tarihçi olan Hartmann, Suriye seyahatinde kaleme aldığı mektupları kitaplaştırmıştır. Onun seyahati daha çok Suriye bölgesinin siyasal ve toplumsal yapısını anlamaya yöneliktir.

${ }^{6}$ Seyahati Preußische Akademie der Wissenschaften tarafindan finanse edilen Oskar Mann'ın mektupları Mojtaba Kolivand tarafindan kitaplaştırılmıștır.

${ }^{7}$ Diplomat, seyyah, arkeolog gibi oldukça farklı yönleri olan Oppenheim, mektepli oryantalistlerin aksine alaylı bir oryantalist olarak ele alınabilir. Seyahatinde bedevilerin yaşamları ve 'Ortadoğu' halkları üzerine detaylı bilgiler bulmak mümkündür.
} 
metin-kritik yöntemini benimseyen ve Doğu dilleri üzerine doktora yapan Sachau, 1869'da Viyana'da Sami dilleri filolojisinde profesör olarak çalışmıştır. Akademie der Wissenschaften (Bilimler Akademisi) üyesi olan Sachau, 1876 yılından itibaren Berlin'de Friedrich-Wilhelm Üniversitesi'nde Sami dilleri bölümünde çalışmış aynı zamanda 1920'ye kadar Seminar für Orientalische Sprachen (Doğu Dilleri Enstitüsü)'nün müdürlüğ̈nü yapmıştır (Mangold 2004: 165; Hanisch 1992: XVIII). Sachau, Sami filolojisinden, İslam fikhı ve bilimi ve Hristiyan teolojisine kadar farklı alanlarda çalışmalar yapmıştır. 19. yüzyılın ikinci yarısında oryantalistlerin belirli bir süre Doğu'da bulunmaları onların kariyerlerinde önemli bir yere sahip olmuştur. Bu deneyimleri ve Arapça lehçeleri konusunda uzmanlaşması ona 1887 yılında kurulan Doğu Dilleri Enstitüsü’nün kapılarını açmıştır.

Sachau, Doğu'yu farklı dönemlerde ziyaret etmiştir ve bunları iki kitap şeklinde yayımlamıştır. İlki bu çalışmanın konusu olan 1879 yılında başladığı ve 1880 yılında tamamladığ1 yaklaşık altı ay süren Reise in Syrien und Mesopotamien (Suriye ve Mezopotamya Seyahati) (1883) adlı seyahatidir. Diğeri gezisini de Am Euphrat und Tigris (Fırat ve Dicle'de) başlığ i ile kitaplaştırmıştır (1900). Sachau, Beyrut'ta başladığ 1 Suriye ve Mezopotamya seyahatine Şam-Halep istikametinde devam ederek Birecik ve Urfa üzerinden yeniden bugün Suriye sınırlarında yer alan Rakka ve Deyr-i Zor şehrine ulaşmıştır. Oradan Musul'a ulaşan Sachau daha sonra bugünkü Türkiye topraklarına girmiş Cizre-Midyat-Mardin ve Diyarbakır istikametinde yoluna devam etmiştir. Daha sonra Siverek-Birecik üzerinden Halep'e oradan Hatay üzerinden İskenderun'a hareket eden Sachau, seyahatini orada sonlandırmıştır. Sachau'nun sınırlara takılmadan Osmanlı taşrasında kırsaldan şehir merkezlerine kadar dolaştığı Osmanlı topraklarında bugün üç ayrı devletin ortaya çıkması onun özellikle bu seyahatini ilginç kılmıştır. 19. yüzyılda Sachau'nun seyahati Doğu-Batı kültür transferi ve bunun bir metne dönüşmesinde iyi bir örnek teşkil eder. Sachau, bir yandan Doğu'nun gizemli, mistik, karmaşık yanını farklı boyutları ile ele alırken diğer yandan onu coğrafi, topografik, antropolojik, sosyolojik, tarihsel, mezhepsel ve dinsel olarak somut bir şeye dönüştürmüştür.

Seyahatinde coğrafya, tarih, siyaset, antropoloji, sosyoloji, filoloji, din, mezhep, jeoloji, arkeoloji, sanat tarihi, şehir tarihi gibi konularda detaylı bilgiler veren belirli bir yol haritası ve ajandası olan Sachau'nun, yolculuğu egzotizm ve macera peşinde koşan seyyahlardan oldukça farklıdır. Onun izlenimlerini seyahat kitabı olarak bastırmasının yanı sıra notlarından daha sonra farklı alanlarda bilimsel çalışmalar yapması oryantalist bir bilgiye dönüşmesine aracı olmuştur. Seyahat, bu bağlamda bilgi üreten bir sürecin adıdır. Sachau'nun hafızası, not defteri, konuşma ve konuşturmaları ise somut anlamda bir bilgi deposudur. Güçlü bir ağın yanı sıra Sachau'nun rahat hareketliliği, yerel yöneticiler ve bölgenin ileri gelenleri ile kurduğu yakınlık onun oryantalist bilgi üretiminde ciddi bir rol oynamıştır. Gidilen yerde seyahate eşlik eden kılavuzlar ve dönemin ulaşım araçları taşra seyahatlerinde deve, katır vb. yük hayvanlarına sahip olma bilgi edinme sürecinin bir parçası olarak kabul edilebilir. Sachau, notlarında bu konudaki deneyimlerinden etraflıca bahseder (1883: 5). Bölgeyi oldukça iyi bilen bir rehber ona göre gün içerisinde büyük oranda bilgi elde edilmesine büyük bir katkı 
sunar. Eğer kılavuz bilgisiz ise Sachau'ya göre seyyahın elinde "bir yalan yumağından başka bir şey” kalmayacaktır (1883: 18). Sachau, bilgi üretiminde kendi gözlemlerini merkeze koyar ve kendisinden önceki seyyahların izlenimlerin üzerine bilgi inşa etmenin oldukça problemli olduğunu iddia eder. Ünlü Alman haritacı Heinrich Kiepert'in haritasını kullanan Sachau, seyyahın bilgi toplamasında ona eşlik eden kılavuzun rolüne de dikkat çekmiştir.

\section{Oryantalist Bilginin Üretimi}

Daha önce bahsedildiği gibi Sachau, seyahat ettiği yerlerde farklı disiplinlere bilimsel malzeme olacak konular hakkında detaylı değerlendirme ve gözlemler yapmıştır. Bir şehre girerken öncelikle orası ile ilgili demografik bilgiler veren Sachau, ardından şehri kategorik olarak dinsel, dilsel ve mezhepsel bir tasnife tabi tutmuştur. Sosyolojikantropolojik ve siyasi gözlemlerini metnin merkezine oturtan Sachau, bunu metin boyunca oldukça geleneksel bir metodolojiye dönüştürebilmeyi başarmış ve bunların oryantalizmin bir malzemesi olarak Batı'ya transferini mümkün kılmıştır. Yani Sachau, izlenimlerini bir kitapta yayımlamanın yanı sıra topladığı/ürettiği bilgilerden müstakil bilimsel makaleler yazarak kaynağından aldığı uygulanabilirliği olan oryantalist bilgiyi aynı zamanda Batı'ya transfer etmiştir. Bilgiyi somut olarak kullandığı yer ise daha önce bahsi geçen oryantalist derneklerdir.

Böylece seyahatte oryantalist bilgi, kuramsallaştıran uygulamaların bir topluluğu olarak ortaya çıkar. Seyyahın gördüklerini analiz becerisi, topladıklarını sorgulama yetisi, metodolojik/filolojik altyapısı, iletişim ağının gücü ve çeşitliliği, bilgiyi pazarlayabilme kabiliyeti onun bilgi üretim sürecinin ne kadar başarılı olduğunu ve bilginin değerini ortaya koyar. Gördüklerine bir gözlemci olarak önyarg1 ve güçlü bir şekilde duygularını yansıtması ise bilginin değerini ve doğruluğunu sorgulamaya açan bir başka duruma dönüşür. Hangi bilginin nerede kullanılacağı meselesi seyahat notlarını bir bütün olarak değil aksine birbirinden bağımsız parçalar olarak daha işlevsel kı1mıştır.

Genel anlamda seyahatnameler, sosyal tarihinin inşasında ve disiplinler-arası çalışmalarda çoğu zaman birinci elden kaynaklar olarak önemli bir fonksiyon icra ederler. Bu yönüyle Osmanlı sosyo-politik yapısını özellikle taşrasını bütün yalınlığı ile tasvir eden Sachau'nun seyahati boyunca evlerin yapı malzemeleri ve bu malzemeden sosyolojik çözümleme denemeleri onun metodolojisinin ilk basamaklarından biridir. Sahadaki pratikleri bilgiyi nasıl ürettiğini anlamaya yardımcı olmaya yeterlidir. Deyr-i Zor şehrinin "kaya taşları ve balçıktan inşa edilmiş oldukça yoksul 1500 evden" ibaret (1883: 262) olduğunu belirten Sachau, başka bir örnekte Suriye'de gittiği “bir köyün arı kovanı modelinde az sayıda kil kulübelerden meydana geldiğini” gözlemler (1883: 52). Cizre ile Midyat arasında bulunan taş ve kerpiçten inşa edilmiş olan oldukça alçak damlı evleri ile köylerin yoksulluğu Sachau'nun dikkatinden kaçmaz. Sachau, içerisinde misafir olduğu haneleri "evlerin çatısı içeride dikilmiş kütüklerle tutturulmuş ve çatılarında üç katman var. Birincisi ince kütükler, ikincisi çalılar ve üçüncü olarak da yuvarlanmış kerpiç...” şeklinde betimler ve belirli sayıda "şekilsiz" odaların birbirlerine 
iliştirildiklerini aktarır (1883: 383). Seyahatinde benzer birçok anlatıyı görmek mümkündür. Görüldüğü gibi Sachau, seyahati boyunca Osmanlı taşrasında mimarinin bölgedeki malzeme ile şekillendiğini gözlemler. Mimari ve yapı malzemeleri üzerine aldığı bu notlar artık Doğu'nun kırsal yaşamı üzerine bilgiye dönüşmüş ve Osmanlı sosyal tarihinin bir malzemesi olmuştur. Ev, Sachau'nun anlatısının merkezi, Doğu'da taşrada hüküm süren yoksulluğun yansıması olarak işlev görür. Evden toplumu, toplumdan ise taşrayı tanımlar. Osmanlı topraklarını dolaşan Sachau'nun bu kadar yoksulluk ve açlıkla karşılaşmasının nedeni 93 Harbi'nin geride bıraktığı yoksullukla açıklanabilir.

Sachau'nun seyahatinin en belirgin özelliği daha önce vurgulandığı gibi yolcuğu boyunca insanlara dokunması olmuştur. Gündelik yaşamdan, kılık kıyafete, yemek kültüründen, 1sınma geleneklerine kadar kendi kültürüne tamamen yabancı olan seyahat tecrübesinde dokunduğu insanları antropolojinin bir malzemesi yapmayı başarmıştır. Osmanlı kırsalından şehirlerine farklı toplumsal katmanlardan bireylerle ve onları karş1laştırma ile zenginleştirdiği izlenimler bugünden o dönemi anlamada artık önemli sosyo-antropolojik veri olmuştur. Sachau'nun “çadırların kurulduğu büyük bir alanda bedevilerin yaşamını izlemek" ifadesi bireyden topluma bilgiyi nasıl inşa ettiğini ortaya koyar (1883: 32). Sachau, bedevi çöllerinde Şammar aşireti ileri gelenleri ile zaman geçirmiş onların konuştukları Arap lehçeleri ile ilgili notlar almıştır. Sachau'nun, "keyifle Şammarların çadırında daha fazla kalabilir, onların yaşamının bütün detayları ile ilgili dersler alabilir, onların lehçelerini öğrenebilirdim” (1883: 312) ifadesi bir seyyah olarak onun nasıl bir yöntem izlediğini ortaya koymaktadır. Bedevilere oldukça yakın ilgi duyan Sachau'nun anlatımında onların çölde çobanlık yaparken kullandıkları en basit malzemelerden hayvan yetiştirme yöntemlerine kadar gündelik tüketim pratikleri bulmak mümkündür. Örneğin Humus Gölü (bugünkü adıyla Bahr-u Kattinah) yakınlarında mola verdikleri zaman öğle vakitlerinde bir bedevi çadırında kahvenin nasıl yapıldığını anlatır: "Ev sahibi tahtadan bir havanda kendi usulüne uygun kahveyi dövmeye başladı ve kısa bir süre sonra bana bir bedevi kahvesi uzattı." Uzatılan kahvenin içerisinde şeker bulunmamasını bedevilerin şeker alabilecek maddi gelirden yoksun olmaları ile açıklayan Sachau, küçük bir ayrıntıdan detaylı sosyolojik çözümlemelerde bulunur (1883: 59-60). Yine bir bedevi çadırında kendisine seyyale adlı üzerinde şeker eritilmiş üzerinden yağ damlayan bir buğday krep ikram edildiğinden bahseden Sachau, (1883: 142) Türklerin pilav, Kürt ve Nasturilerin ise bulgur tükettiklerini belirterek yemek kültürü ile kültürel geçişkenliklere ve farklılıklara dikkat çeker. Sachau'nun anlatısından hareketle Doğu'da buğdayın mutfağın temeli olduğu ve onun tükendiği anda ise -tam da onun dolaştığı zamanlarda- insanların kıtlık ile ne oranda yüzleştikleri anlaşılabilir (1883: 332). ${ }^{8}$ Gözlemlediği toplumlarda cinsiyet, sınıf, iktidar, siyaset, din ve inançlarla ilgili sorular soran seyyahlar verilen cevaplar üzerinden antropolojinin bir parçası olacak bilgi üretirler. Bunlar aynı zamanda Doğu'yu anlamanın bilimsel yollarından biri olan oryantalizmin de malzemesidir. Bu

\footnotetext{
${ }^{8}$ Sachau, seyahati esnasında diğer bölgelerde olduğu gibi Kürtlerin meşe palamudunu un yapmak için kullandıklarını belirtir (1883: 332). Her gün 4-5 kişinin açlıktan öldüğü Cizre’ye vardığında Sachau, kıtlığı somut bir şekilde hisseder. Orada satın alınacak tek ekmek dahi olmadığını belirtir (1883: 380).
} 
bağlamda düşünüldüğünde seyahatnameler bilginin disiplinler arasında transferini de mümkün kılan araçlar olarak ele alınabilirler. Farklı bölgelerdeki bedevilerin aile yaşantısına, evlilik yapılarına, kadın ve erkek arasındaki iş bölümü ve toplumsal ilişkilere, yerleşim modellerine, mutfaklarına (çadır şekilleri vb.) geniş bir yer veren Sachau, böylece kadınların bedevi toplumundaki sosyolojik ve antropolojik yerine de 1şık tutar (1883: 307-308). Hatta bir bedevi çadırının içerisinde bir hasırla ayrılan kadın bölümünün içerisinde hangi ev eşyalarının bulunduğuna dair en küçük detayları bile betimleyen Sachau, çadırdaki haremlik selamlık kültürünün nasıl işlediğine dair detaylı bilgi aktarır (1883: 309-310). Gündelik yaşamın bir parçası olan misafirlik ritüeli neredeyse gittiği her yerde birilerine konuk olan- Sachau'nun seyahatinde önemli bir antropolojik malzemeye dönüşür. Sachau, bir bedevi çadırıyla ilgili izlenimlerini şöyle aktarır: "Misafir ağırlamak şeyhin görevidir. Ortalama bir bedevi çadırına girmiş olan bir yabancıyı dişarı atmayacaktır. Fakat onu daha iyi bir yer ve yemek ve kahve imkânları için şeyhe götürmek için konuşacaktır" (1883: 141). Bedevilerin misafir kabulünde önemli bir ritüel olan kahve ikramı Sachau'nun anlatımında oldukça canlı bir betimleme ile aktarılır.

\footnotetext{
Hemen kahve yapıldı. Küçük fincan rutin bir şekilde etrafta döndü. Zira çölde kahve şehirlerde olduğu gibi bir fincan içilmez, bilakis üç dört ve daha fazla ateşin üzerinde köpüren büyük tencere boşalana kadar içilir. Fincan, bütün daireyi katı bir hiyerarşiye göre dolandıktan sonra tekrar onur konuğuna gelir sıra ve öyle devam eder (1883: 141).
}

Sachau, böylece kahve üzerinden bedevi çadırında hayatın nasıl aktığının yanı sıra uzun coğrafi tasvirler ve iklim ile ilgili de çok geniş betimlemeler yapar. Bu bilgiler günümüzde bile iklim değişimlerinin takibinde önemli veriler olarak kullanılmaya elverişlidir. Buna ek olarak ürettiği coğrafi ve iklim bilgileri daha sonra bölgeye gidecek diplomat ve askerler için de başvuru metinleri olarak işlev görmüş olabilirler. Kuraklığın nasıl bir sosyoloji ortaya çıkardığını (1883: 15) sosyal ve iktisadi açıdan tahlil eden Sachau, bu bilgileri Batı'ya aktararak kendi döneminde 'Ortadoğu' iktisadının anlaşılmasında önemli katkıda bulunmuştur. Sachau, seyahatinde bir taraftan Osmanlı toplumunun sosyo-antropolojik kodlarına dokunurken diğer taraftan çeşitli siyasi analizler yapar. Onun notlarında günlük sıradan bir olaydan hareketle Osmanlı taşra yönetimi ve taşrada siyasetin nasıl işlediğine dair oldukça fazla anlatı bulmak mümkündür. Kasım 1878'de Suriye valiliğine tayin edilen Mithat Paşa idaresinde Beyrut Reformları'nın nasıl işlediği ya da merkez-taşra ilişkisinde bir vali olarak valinin konumu üzerine notları örnek olarak verilebilir. Sachau'nun anlatılarından Osmanlı hükümetinin taşrada oldukça zayıf olduğu sonucuna varılabilir. Zira Sachau, Deyr-i Zor şehrinden Habur Vadisi'ne gitmek isterken Şammar aşireti reisi Faris Ağa'dan icazet alarak güvenliğini sağlamayı düşünmüştür. Sachau'nun seyahati göz önünde tutularak Osmanlı taşrasına gelen seyyahların genelde bölgede hâkim olan aşiret reislerinin ya da bir devlet görevlisinin sağladığı muhafızlarla hareket ettiği anlaşılmaktadır. Sachau, aşiretlerin güçlü olduğu yerlerde aşiret reisinin, devletin güçlü olduğu yerlerde ise valinin adıyla hareket etmiştir (1883: 12-266). Osmanlı taşrasında yerel yöneticileri en 
çok uğraştıran problemlerin başında güçlü yerel yapılarla baş edilememesi gelmektedir. Klasik dönemde eşkıyalığa dönüşen cemaat yapılanmaları ve ayanlar, devleti Celali sorunuyla mücadele etmek zorunda bırakmıştır. Yereldeki eyalet veya kaza yöneticilerinin kontrol etmekte zorlandıkları bu güçlü yapılar içerisinde aşiretler gelmektedir. Devlet geliştirdiği iskan politikaları ve aşiretlerle uzlaşma ve savaşma gelgitleri içerisinde pragmatik çözümler üretmeye çalışmıştır. Mesela devlet güçlü olduğunda aşiretlere boyun eğdirmiş, sürgün ve izole etmiş gerektiğinde ise aşiret reislerini ağır şekilde cezalandırmıştır. Ancak çoğu zaman kontrol altına almakta zorlandığ1 aşiretin reislerine resmi görevler, hil'at, nişan, hediye ve maaşlar bağlamıştır. 19. yüzyılda Osmanlı devlet otoritesinin zayıflaması, ordunun yapısının bozulması, toprak ve vergi sistemindeki aksaklıklar, anarşi ve ayaklanmalar bu durumun oluşumunda etkili olmuştur (Akman 2017: 234-250). Şammar Arap aşireti Osmanlı idarecilerin Milli İbrahim Paşa'nın onları güneye sürmelerine kadar baş etmekte zorlandıkları en güçlü ve Ziya Gökalp'ın tabiri ile çapulcu, yağmacı adeta bir beşeri afet olarak tanımlanmıştır (2011: 69). Bu büyük aşiretin izni olmadan bölgede seyahat etmek veya onlara haraç ödemeden ticaret yapmak mümkün değildi. Çölün bu seyyar, saldırgan ve güçlü aşiretleri kendi otantik adet ve görenekleri ile batılı seyyahların dikkatini çektiği gibi, reislerine verdikleri çeşitli hediyelerle bölgede rahatça seyahat etmelerine imkân sağlamıştır. Söz konusu bu siyasi durum Sachau'nun notlarında açık bir şekilde gözlemlenebilir.

Sachau, henüz seyahatnamenin giriş kısmında İstanbul Konferansı'ndan (Tersane Konferans1) ${ }^{9}$ sonra Osmanlı'nın finans ve asker kaynağı Avrupa değil 'Küçük Asya'dır" şeklinde bir iddiada bulunur ve benzer siyasi yaklaşımları seyahati boyunca sıklıkla tekrar eder. Sachau, özellikle 19. yüzyılın sonlarında siyasi açıdan oldukça problemli bir bölgesi olan Suriye-Lübnan izlenimlerini duyduklarını yerinde görme, gördüklerini kendi yorumları ile betimleme yöntemi ile siyasal-oryantal bir bilgiye dönüştürmede oldukça yeteneklidir. Zaten kendi ifadesi ile yaptığı şey bir araştırma seyahatidir (1883: 3). Alman arşivlerine yansıdığı şekliyle Sachau, bilimsel bir seyahat yaptığını Alman makamlarına özellikle vurgulamıştır.

\footnotetext{
Türk hükümetinin benim kazıları not edeceğim ve hazineleri götüreceğime dair bir endişeye düştüğü bir durumda benim esasen kazılarla ilgili bir niyetimin olmadığı ve ellerime tesadüfen önemli eserlerin düşmesi durumunda ise bunların anında Türk hükümetine teslim edeceğim beyan edilebilir (BArch R 901/ 37739, 3 klasör içerisinde). ${ }^{10}$
}

\footnotetext{
91875 yılında patlak veren Hersek ayaklanması bir y1l sonra Bulgarların isyanı ve Osmanlı-Sirp ve Karadağ savaşları Balkan krizine dönüşmüştür. Osmanlı Devleti'nin Balkan coğrafyasının yönetim şartlarını düzenlemek amacıyla Avrupa ülkelerinin baskısı sonucu krizi uluslararası düzeyde çözme girişimi İstanbul Konferansı'nı doğurmuştur. Konferans 23 Aralık 1876 - 20 Ocak 1877 tarihleri arasında İstanbul'daki Haliç Tersaneleri'nde gerçekleştirilmiştir. Bkz. (Aydın: 2016).

${ }^{10}$ Sachau'nun izin için Alman Dışişleri Bakanlığı'na (müşavirliğe) yazı̆̆ı 6 Haziran 1879 tarihli mektup
} 
Sachau'nun seyahati esnasında inşa ettiği toplumsal, siyasal, ekonomik bilgiler Osmanlı Devleti'nin Almanya açısından siyasi olarak önem arz etmeye başladığı dönemde farklı bir boyut kazanmıştır. Bu nokta-i nazarla bakıldığında Sachau'nun seyahati Alman emperyalizminin Osmanlı topraklarında ön keşif denemesi olarak nitelendirilebilir. Sachau, emperyal bir arayıştan ziyade bilimsel araştırmalar yapmış olsa da onun seyahatinde dönemin baskın Fransız ve İngiliz seyyah ve oryantalistlerin Osmanlı topraklarındaki aktivitelerine karşı bir rekabet açıkça sezilir. Ona sağlanan devlet desteği de buna bir kanıttır. 'Ortadoğu'da' sömürgeleri olmayan Almanya gibi bir imparatorluk için bu bilgiler nasıl ve nerede işlevsel hale geldi sorusunun cevabı Doğu Dilleri Enstitüsü'nde aranmalıdır. Sachau'nun diğer Alman meslektaşlarına nazaran erken dönem Doğu tecrübesi ona söz konusu enstitüsünün kapılarını açmıştır. Zira Sachau, uzun y1llar bir oryantalist-sömürge kurumu olan bu kurumda yönetici olarak çalışmış ve tecrübelerini burada uygulama imkânı bulmuştur.

\section{Oryantalist Bilginin Akademik Metne Transferi}

Sachau, gittiği her yerde yazma eserlere ulaşmayı denemiş ve elde ettiği yazmaları bilimsel metinlere dönüştürmüştür. Onun seyahati daha önce bahsedildiği gibi farklı disiplinlere malzeme olabilecek derinlikte bilgi toplama sürecidir. Çalışmanın bu bölümü Sachau'nun elde ettiği bilgileri bilimsel metinlere nasıl dönüştürdügünü incelemektedir.

Sachau, bir şehre girerken arkeolojik araştırmaların ardından cami, medrese ve özel kütüphanelerde Arapça ve İslam eserlerini, Sami dilleri profesörü olması nedeniyle manastır ve kiliselerde ise bulabildiği Süryanice, İbranice yazmalar üzerinde çalışarak notlar almıştır. Suriye'de Karyeten adlı bir köyde (bugün belde) yazmalara ve eski kitaplara sahip olan bir adamı heyecanla ziyaret etmesi ve bunları incelemesi (1883: 3031) ve Mardin'de Deyrul Zaferan manastırını ziyaretinde asıl amacının patriklik kütüphanesini incelemek olduğunu aktarması bu çabaya somut örnekler olarak verilebilir (1883: 64).

Sachau, incelemelerinde en küçük ayrıntıları dikkate alarak Musul kırsalında yaşayan Doğu Süryanilerinin konuştuğu dil hakkında detaylı bilgiler vermiştir. Bu yöntem onun anlatılarında birçok yerde somutlaştırılabilir. Söz konusu metinleri araştırırken Musul'daki bir Nasturiden yardım alan Sachau'nun konuşulan dili öğrenme girişimi bu sürecin önemli deneyimlerinden biridir (1883: 354-355, 362-364). Musul'daki izlenimlerini Almanya döndükten sonra zenginleştirip Skizze des FellichiDialekts von Mosul (Musul Fellahi Dialekti Krokisi) adlı müstakil filolojik-akademik bir çalışma olarak yayımlamıştır. Bu kitapta seyahat izlenimlerinin oryantalist bilgiye nasıl dönüştügünü kendi ifadesi ile "öğretmenim aslen Ankavalı (bugün Erbil yakınlarında) ama Kerkük civarında doğmuş ve yıllar önce Musul'a yerleşmiş olan, daha önce bahsettiğim (Reise in Syrien und Mesopotamien), Jeremias'tı" şeklinde tasvir eder (Sachau 1895: 4; Sachau 1896: 179). Musul'dan sonra Dicle sinırı boyunca bölgenin dil haritasının değiştiğini, Arapçanın yerini daha çok Kürtçeye bıraktığını, ifade eden Sachau, Yezidilerin ise sadece Kürtçe konuştuğunu iddia eder. Nasturi 
erkeklerin ise Kürtçe ve kendi yerel dillerini konuştuklarını belirten Sachau, Nasturi kadın ve çocukların ise Kürtçe bilmediklerini aktarır. Nasturiler gibi Yakubilerin de bu bölgede Arapça ve Kürtçe konuştuklarını gözlemleyen Sachau, söz konusu coğrafyada Arapçanın geniş bir kesim tarafından konuşulduğunu ifade eder. Bunun nedeni ona göre ticari olarak bölgenin Musul'a olan bağımlılığıdır (1883: 374). Sachau'nun izlenimlerini metne aktarımı bir yandan oryantalist bilginin nasıl oluştuğunu açıklarken diğer yandan bu bilginin Avrupa'ya nasıl transfer edildiğini ortaya koymaktadır. Hentsch'in ifadesi ile:

...çok geçmeden gezginler çantalarında metinlerle dönecektir, tıpkı daha sonra gemiler dolusu taşlarla (heykeller, alçak kabartmalar, dikili taşlar vb.) dönüleceği gibi. Ama hepsinden önemlisi, bu gezginler ilk ağızdan hikâyeler anlatmakta, o zamanlar söylendiği gibi, Doğu'ya ilişkin malzemenin ana kaynağı oluşturan raporlar sunmaktadır. Bu malzeme Doğulu halkların (özellikle Türklerle İranlıların) tarihini konu alan eserlerle zenginleşecek ve ilerde Doğu ile bilgilerin sistemli olarak sınıflandırılmasını sağlayacaktır (Hentsch 2008: 130).

Avrupalı oryantalist-seyyahlar, hem Doğu metinlerini beraberlerinde götürerek Batı'da oryantalizmin kurumsallaşmasına ve Şark yazmaları kütüphanelerinin kurulmasına katkı sunmuşlar hem de eski yerleşim yerlerini fotoğraflayarak Osmanlı topraklarında arkeolojik kazıları başlatmışlardır. Daha önce vurgulandığı gibi Sachau'nun seyahati çok yönlü ve farklı disiplinlerden zengin malzemeler içeren bir kitaba dönüşmüştür. Gittiği yerlerde bölgenin tarih ve arkeolojisi üzerine yaptığı gözlemler, aldığı notlar, çizdiği krokiler ve çektiği fotoğraflar bu seyahatin önemli somut çıtıları olarak kabul edilebilir. Daha sonra buradaki çalışmaları detaylı bir şekilde işleyerek bilimsel makalelere dönüştürmüştür. Sachau'ya göre Halep'te yaşayan tüccarların antik yerleşim yerlerinin bulunmasında çok ciddi katkıları olmuştur ve ona göre tüccarlar bu konuda takdiri hak etmişlerdir (1883: 104). Bu yaklaşımdan seyyahların daha önce var olan bilgiler üzerine yeni bilgi ve izlenimleri nasıl inşa ettikleri anlaşılabilir. Özellikle Doğu arkeoloji keşiflerinin gelişim sürecinde de Sachau'nun bu tespitinin önemli bir yeri vardir.

Sachau, Suriye'de Hama'nın kuzeybatısında bulunan Larissa'dan (bugün Şayzar) Apemea'ya (Epemiye) kadar olan seyahati boyunca elinde antik yerleşim yerlerini gösteren bir kroki ile irili ufaklı birçok yeri incelemiş ve mezar taşlarındaki Grekçe metinler üzerinde araştırmalar yapmıştır. Seyahati sırasında ulaşabildiği tüm kitabe ve yazıtları detaylı bir şekilde tetkik etmiş, haritalar çizerek (1883: 69-88) antik şehirlerin yapı malzemesi ile ilgili karşılaştırmalar yapmıştır. Sachau, antik dönemde oldukça önemli bir ticaret ve kültür merkezi olan Palmyra ile ilgili geniş tasvirler yapmış ve daha sonra burada tuttuğu not ve çizimlerden Palmyrenische Inschriften (Palmira Kitabeleri) (1881: 728-748) adlı bir çalışma çıkarmıştır. Onun Palmyra izlenimleri seyahat-oryantalizm-arkeoloji ilişkisine iyi bir örnek teşkil eder. Burada Sachau'nun işlevi antik dönemde yazılmış kitabeleri deşifre ederek arkeolojinin bir 
parçasına dönüştürülmesidir. Bu durum bir oryantalistin ölü metinlere nasıl yeniden hayat verdiği şeklinde betimlenebilir.

Sachau, seyahatin ilerleyen dönemlerinde Halep'in doğusunda yer alan Zebed civarında gözlemlerde bulunmuş ve burada Zebed Kitabesi olarak adlandırılan üç dilli (Grekçe, Süryanice ve Arapça) metni incelemiştir. Hristiyan Aziz Sergius adına M.S. 512 yılında inşa edilen bir bazilika (1883: 126) kalıntısı olan bu kitabe üzerine Sachau, Eine dreisprachige Inschrift aus Zebed (Üç Dilli Zebed Kitabesi) adlı bir makale yazmıştır (1881: 169-190). ${ }^{11}$ Araştırmalarına Urfa'da devam eden Sachau, şehirde bulunduğu sıralarda Balıklı Göl ve çevresi ile ilgili uzun tasvirler yaparak izlenimlerini bir kroki ile desteklemiştir. Bu çevrede bulunan bütün kitabelerdeki yazıları kopyalayan (1883: 197-200) Sachau, daha sonra bu kopyalar üzerinde detaylı bir şekilde çalışmıştır. Ardından bu kitabeler ile ilgili olarak Edessenische Inschriften (Edessa Kitabeleri) (1882: 142-167) adlı bir makale kaleme almıştır. Bu çalışmasında seyahatinde sırasında kopyaladığ 1 kitabe yazıtlarını metin olarak çevirileri ile beraber vermiştir.

Sachau, Nusaybin ve Dara'da araştırmalar yaptıktan sonra günümüzde Kızıltepe sınırları içerisinde bulunan Tel Ermen'e hareket etmiştir. Orada tarihçiler arasında ciddi bir tartışma konusu olan Selevkosların mirası üzerine Armenia kralı II. Tigranes tarafından kurulan Tigranokerta antik şehrinin konumu üzerine detaylı incelemelerde bulunmuştur. Armenia’yı Kuzey Mezopotamya ve Kilikya ile birleştirerek büyük bir imparatorluk kuran II. Tigranes bu şehri M.Ö. 1. yüzyılda krallığının yeni başkenti olarak inşa ettirmiştir. Her ne kadar bazı tarihçiler bu yerleşim yerinin Silvan'da olduğunu iddia etseler de onların aksine Sachau, söz konusu şehrin Tel Ermen'de olduğu konusunda oldukça 1srarcıdır (1883: 401-403). Yaptığı araştırmaların ardından Tigranokerta'nın konumu üzerine Über die Lage von Tigranokerta (Tigranokerta'nın konumu Üzerine) (Sachau 1881: 3-4) adlı bir makale yazmış ve burada bu konudaki iddialarını kanıtlamaya çalışmıştır. Bunun yanı sıra birçok çalışmasında bu seyahatte edindiği bilgileri kullandığı ve seyahatine referans verdiği görülmektedir. $\mathrm{Bu}$ referanslardan birine de Baal-Harran in einer Altaramäischen Inschrift (BaalHarran'da Eski Aramice Üzerine Bir Kitabe) adlı Süryanice bir kitabe üzerine yaptığı çalışmada rastlanır (Sachau 1895: 121).

\section{Sonuç}

Alman oryantalizminin Doğu ile kurduğu doğrudan ilişkide oryantalist seyyahların oldukça önemli bir rolü vardır. Almanların Fransız ve İngilizlere nazaran bilimsel Doğu seyahatlerine daha önce başlamaları, Alman devlet kurumlarının bu rekabeti desteklemede önemli bir gerekçe olmuştur. Bu rekabet vurgusunu Sachau'da da görmek mümkündür. Sachau'nun yüzey çalışmaları Almanların Osmanlı topraklarında yapacakları arkeolojik çalışmalar için önemli bir başlangıç sayılabilir. Onun seyahati sonraki birçok araştırmacı için neredeyse ilk basamak olmuştur. Sachau'nun seyahati

\footnotetext{
${ }^{11}$ Sachau, kitabenin Arapça olan kısmının daha önce Wetzstein sonra da Waddington tarafından yayımlanan Arap dili ile yazılan en eski anıt olduğunu iddia etmiştir. Sachau'nun seyahati esnasında dergiye gönderdiği 27 Aralık 1879 tarihli mektup (1880: 172)
} 
oryantalist bilgi üretimi ve transferinde önemli bir araca dönüşmüştür. Yani Sachau, farklı disiplinlere malzeme olabilecek zenginlikte oryantalist bilgi üretmiş ve onu akademik metne dönüştürerek Batı'ya transfer etmiştir. Elde ettiği bilgileri kullandığ 1 ilk yer ise yöneticilik yaptı̆̆ı, Alman sömürgelerine diplomat yetiştiren Seminar für Orientalische Sprachen adlı enstitü olmuştur. Sachau'nun seyahati sonrası yaptığı çalışmalar, seyahat yazını ve bilimsel çalışmalar arasındaki geçişkenliklere somut veriler teşkil eder. Farklı meslek gruplarından seyyahların gezileri sonucu 19. yüzyılda ortaya çıkan seyahat literatürü, bünyesinde kolonyal izler taşımaktadır. Sachau'nun seyahati Doğu'da diğer rakipleri gibi var olduğunu kanıtlamak isteyen Alman kurumları tarafından desteklense de Sachau'nun seyahatinde bilimsel keşif amaçladığı sonucu çıkarılabilir. Sachau, yazdığı mektuplarda Almanların Doğu'daki bilimsel keşiflerde geç kaldıklarını vurgulamıştır. Sachau'nun bilgi üretimi Almanya'da oryantalizmin kurumsallaşmasında ve daha sonra emperyalizmin altın çağında oryantalist bilginin sömürge bilgisini inşada önemli bir rol oynamıştır.

\section{Kaynakça}

Arşiv Kaynakları

Das Bundesarchiv (BArch) Berlin-Lichterfelde

R 901/ 37739

\section{Birinci el ve Araştırma Kaynaklart}

Akman, Ekrem (2017): 19. Yüzyllın İkinci Yarısında Siverek (Şehir, Mekân ve İnsan). Doktora Tezi. Mardin Artuklu Üniversitesi Sosyal Bilimler Enstitüsü.

Aydın, Mithat: İstanbul Konferansı. Türkiye Diyanet Vakfi İslam Ansiklopedisi.(2016) https://islamansiklopedisi. org.tr/istanbul-konferansi (erişim: 12 Haziran 2019)

Belck, Waldemer: Untersuchungen und Reisen in Transkaukasien, Hoch-Armenien und Kurdistan. Globus. 63/22 (1893). 349-352.

Becker, Carl Heinrich (1932): Eugen Prym. Islamstudien: Vom Werden und Wesen der islamischen Welt. Bd. 2. (Ed.) Hans Heinrich Schaeder. Leipzig: Verlag Quelle und Meyer. 456-462.

Bulut, Yücel (2014): Oryantalizm Kısa Tarihi. İstanbul: Küre Yayınları.

Brenner, Peter J. (1990): Der Reisebericht in der deutschen Literatur: Ein Forschungsüberblick als Vorstudie zu einer Gattungsgeschichte. Tübingen: Max Niemeyer Verlag.

Edwards, Justin/Graulund, Rune (2011): Introduction: Reading Postcolonial Travel Writing. Justin (Ed.). Edwards/Rune Graulund. Postcolonial Travel Writing Critical Explorations. Chippenham and Eastbourne: CPI Antony Rowe. 1-17.

Gökalp, Ziya (2011): Kürt Aşiretleri Hakkında Sosyolojik Tahliller. İstanbul: Kaynak Yayınları.

Gülçur, Sevil (2013): Entdeckungsreisen in Osmanischer Zeit. Der Anschnitt Zeitschrift für Kunst und Kultur im Bergbau. 25. 41-47.

Hanisch, Ludmila (2003): Die Nachfolger der Exegeten: deutschsprachige Erforschung des Vorderen Orients in der ersten Hälfte des 20. Jahrhunderts. Wiesbaden: Otto Harrassowitz Verlag. 
Hanisch, Ludmila (1992): Islamkunde und Islamwissenschaft: Der Briefwechsel zwischen Carl Heinrich Becker und Martin Hartmann (1900-1918). Leiden: Dokumentatiebureau Islam-Christendom.

Hartmann Martin (1913): Reisebriefe aus Syrien. Berlin: Dietrich Reimer Verlag.

Hentsch, Thierry (2008): Hayali Doğu, çev. Aysel Bora. İstanbul: Metis Yayıncılık.

Herzfeld, Ernst/ Sarre Friedrich (1911-1920): Archäologische Reise im Euphrat- und Tigris-Gebiet 14 Berlin: Dietrich Reimer Verlag.

Kolivand, Mojteba (2014): Persische und kurdische Reiseberichte Die Briefe des Berliner Orientalisten Oskar Mann während seiner beiden Expeditionen in den Vorderen Orient 1901-1907. Wiesbaden: Harrassowitz.

Lehmann-Haupt, Carl (1910): Armenien einst und jetzt. Reisen und Forschungen. Berlin: B'Behrs Verlag.

Lehmann-Haupt, C.-Belck Waldemer: Reisebriefe von der armenischen Expedition. Mittheilungen der Geographischen Gesellschaft in Hamburg. 15 (1899). 1-23.

Mangold, Susanne (2004): Eine weltbürgerliche Wissenschaft: Die deutsche Orientalistik im 19. Jahrhundert. Stuttgart: Franz Steiner Verlag.

Oppenheim, Max von (1899): Vom Mittelmeer zum Persischen Golf, durch den Hauran, die syrische Wüste und Mesopotamien. Bd. 1-2 Berlin: D. Reimer E. Vohsen.

Prass, Reiner: Forschungsreise und Wissensproduktion in Afrika in der Mitte des 19. Jahrhunderts. (2019), 1-9. https://www.europa.clio-online.de/essay/id/artikel-4762 (erişim: 14 Haziran 2019)

Sachau, Eduard (1883): Reise in Syrien und Mesopotamien. Berlin: F.A. Brockhaus.

Sachau, Eduard (1895): Skizze des Fellichi-Dialekts von Mosul. Berlin: Verlag der Königlichen Akademie der Wissenschaften.

Sachau, Eduard: Über die Lage von Tigranokerta. Abhandlungen der Königlichen Akademie der Wissenschaften zu Berlin 1880 II (1881). 3-75.

Sachau, Eduard: Über die Poesie in der Volkssprache der Nestorianer. Sitzungsberichte der Königlich Preussischen Akademie der Wissenschaften zu Berlin I (1896).179-215.

Sachau, Eduard: Baal-Harran in einer Altaramäischen Inschrift auf einem Relief des Königlichen Museums zu Berlin. Sitzungsberichte der Königlich Preussischen Akademie der Wissenschaften zu Berlin (1895). 119-122.

Sachau, Eduard: Palmyrenische Inschriften. Zeitschrift der Deutschen Morgenländischen Gesellschaft. 35/4 (1881). 728-748.

Sachau, Eduard: Aus einem Briefe des Herrn Professor Dr. Sachau. Zeitschrift der Deutschen Morgenländischen Gesellschaft, Bd. 34 (1880). 172-174.

Sachau, Eduard: Eine dreisprachige Inschrift aus Zébed. Monatsberichte der Königlich Preussischen Akademie der Wissenschaften zu Berlin, (1881). 169-190.

Sachau, Eduard: Edessenische Inschriften. Zeitschrift der Deutschen Morgenländischen Gesellschaft, Bd. 36 (1882). 142-167.

Sarre, Friedrich (1895): Reise in Kleinasien: Forschungen zur Seldjukischen Kunst und Geographie des Landes. Berlin: Dietrich Reimer Verlag.

Sharp, Joanne P. (2002): Writing travel Travelling writing: Roland Barthes detours the Orient. Environment and Planning D Society and Space. 20/2. 155-166. 
Soukah, Zouheir (2010): Das Orientbild in G. Rohlfs erster Marokko-Reise. München.

Soukah, Zouheir (2016): Der Orient als kulturelle Selbsterfindung der Deutschen. Doktora Tezi. Philosophische Fakultät der Heinrich-Heine-Universität Düsseldorf.

Unverhaun, Katja (2012): Ein unkonventioneller Blick auf deutsche Provinz: Die Fußreise des Thomas Hodgskin durch das nördliche und mittlere Deutschland. Doktora Tezi. Philosophischen Fakultät der Georg-August-Universität Göttingen. 


\section{Ekler}

Eduard Sachau'nun 6 Haziran 1879 tarihli mektubu

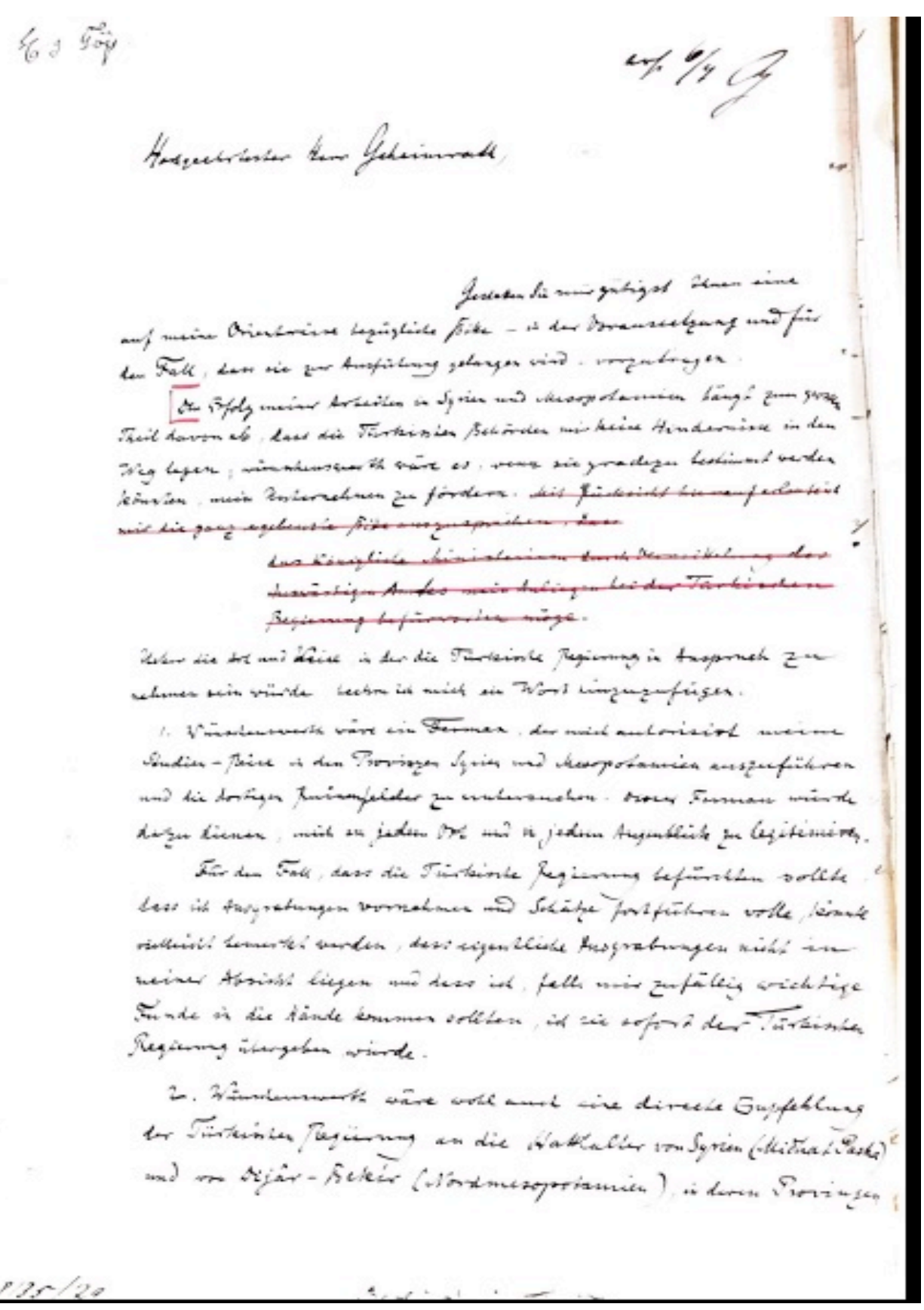


Eduard Sachau'nun 25 Haziran 1879 tarihli mektubu

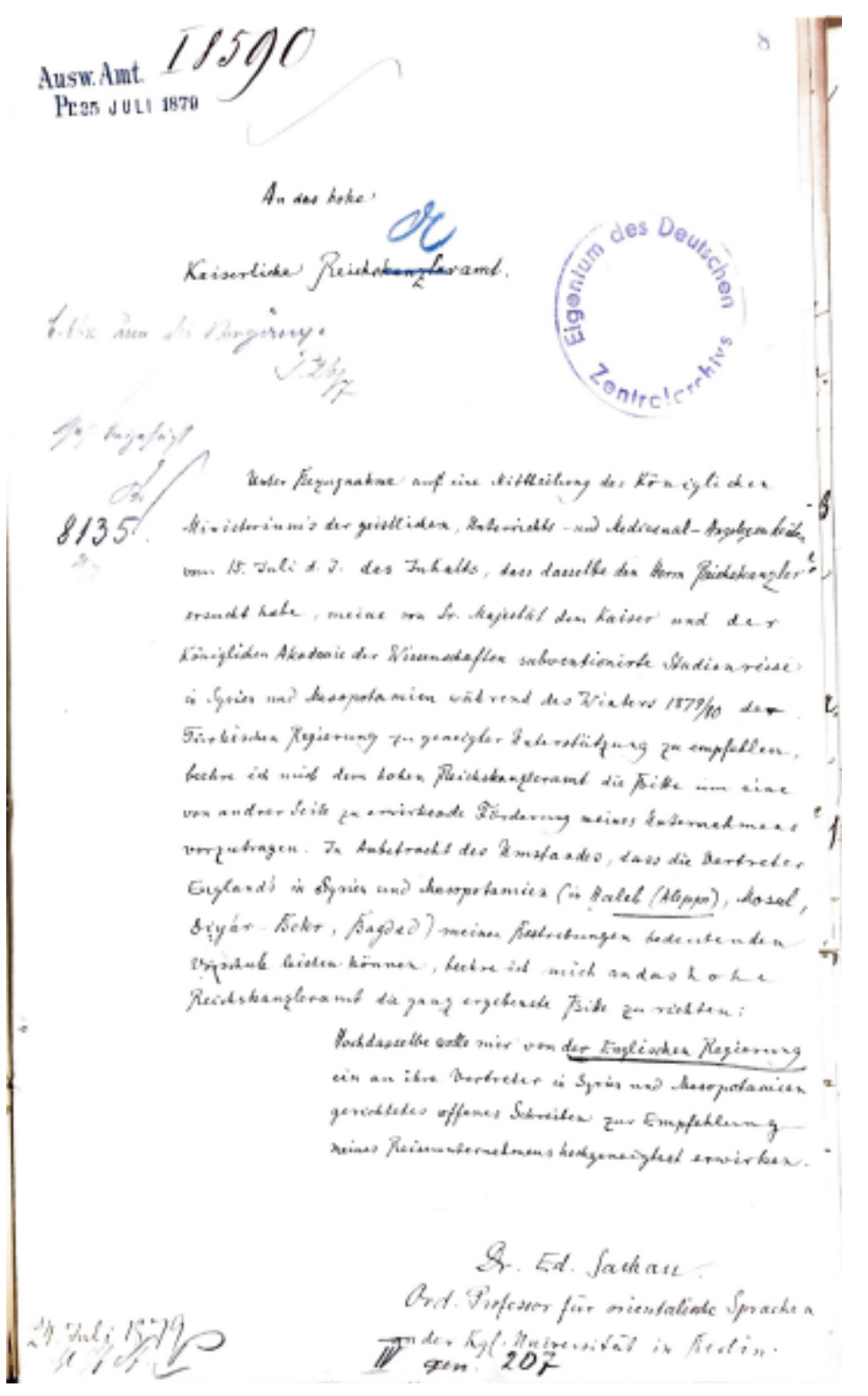

